\title{
ANALISIS KANDUNGAN PROLIN PLANLET JERUK KEPROK BATU 55 (Citrus reticulata Blanco var. crenatifolia) SETELAH DIINDUKSI LARUTAN ATONIK DALAM KONDISI CEKAMAN KEKERINGAN SECARA IN VITRO
}

\author{
Anis Ashari ${ }^{*}$, Endang Nurcahyani²*, Hardoko I. Qudus ${ }^{2}$, Zulkifli ${ }^{1}$. \\ 1. Jurusan Biologi FMIPA Universitas Lampung \\ 2. Jurusan Kimia FMIPA Universitas Lampung
}

Jl. Prof. Dr. Soemantri Brojonegoro No.1, Bandar Lampung, Indonesia 35145

endang_nurcahyani@yahoo.com

\begin{tabular}{|l|}
\hline$\underline{\text { Artikel Info }}$ \\
Diterima \\
tanggal \\
20.01 .2018 \\
\\
Disetujui \\
publikasi \\
tanggal \\
30.04 .2018 \\
\\
Kata kunci : \\
Citrus nobilis \\
Lour, PEG \\
6000, var \\
microcarpa \\
Hassk
\end{tabular}

\section{ABSTRAK}

Jeruk keprok batu 55 merupakan salah satu tanaman yang dibudidayakan di Indonesia umumnya didaerah Jawa Timur yang berada pada ketinggian 700 $1200 \mathrm{~m}$ dpl. Salah satu masalah utama budidaya jeruk di Indonesia adalah terdapat beberapa daerah di Indonesia yang kondisi tanahnya kering. Penelitian ini bertujuan untuk mengetahui larutan atonik yang optimum dan konsentrasi PEG yang toleran untuk pertumbuhan planlet jeruk keprok batu 55 (Citrus reticulata Blanco var. crenatifolia) terhadap cekaman kekeringan menggunakan (PEG) 6000, serta mengetahui karakter spesifik pada planlet jeruk keprok batu 55 meliputi kandungan prolin. Penelitian ini telah dilaksanakan pada bulan NovemberDesember 2017 di Laboratorium Botani Ruang Kultur Jaringan Jurusan Biologi Fakultas Matematika dan Ilmu Pengetahuan Alam Universitas Lampung menggunakan Rancangan Acak Lengkap Faktorial, yang terdiri dari 2 faktor yaitu faktor A larutan atonik ( $0 \mathrm{~mL} / \mathrm{L}, 2 \mathrm{~mL} / \mathrm{L}, 3 \mathrm{~mL} / \mathrm{L})$, faktor B konsentrasi PEG ( $0 \%$, $2 \%, 4 \%$ ), sehingga didapatkan 9 kombinasi perlakuan yang masing-masing perlakuan di ulang sebanyak 3 kali. Homogenitas ragam menggunakan uji Levene dilanjutkan dengan analisis ragam taraf nyata 5\% dan uji lanjut dengan BNT taraf nyata 5\%. Hasil Penelitian menunjukkan bahwa konsentrasi larutan atonik yang optimum adalah 3 $\mathrm{mL} / \mathrm{L}$, sedangkan konsentrasi PEG 6000 yang toleran terhadap seleksi planlet jeruk keprok batu 55 adalah 4\%. Karakter ekspresi planlet jeruk keprok batu 55, semakin tinggi konsentrasi PEG 6000 maka kandungan prolin semakin meningkat.

\section{ABSTRACT}

Siam pontianak orange planlet's (Citrus nobilis Lour. var. microcarpa Hassk.) is one of the important fruits in Indonesia. Orange has a high economic value both in the form of fresh and processed and as a source of vitamins and minerals. The purpose of this research is to know the optimum concentration of atonic solution; concentration of Polyethylene Glycol (PEG) tolerant to drought stress for selection of Siam plantlets in vitro; knowing the interaction between an atonic solution and PEG 6000 for knowing and analyzing the specific expression character of a conjoined orange planlet tolerant of drought stress including total dissolved carbohydrate content. This research was conducted in $3 \times 3$ factorial experiments. Factor A was an atonic solution to 3 concentration levels: $0 \mathrm{~mL} / \mathrm{L}, 1 \mathrm{~mL} / \mathrm{L}$, and $2 \mathrm{~mL} / \mathrm{L}$. Factor B is PEG 6000 to 3 levels of concentration: $0 \% \mathrm{w} / \mathrm{v}, 3 \% \mathrm{w} / \mathrm{v}$, and $5 \% \mathrm{w} / \mathrm{v}$. Levene test, variance analysis at $5 \%$ real level. Variance analysis was performed at $5 \%$ real level. The results showed that atonic solution to high drought level significantly decreased total dissolved carbohydrate content. From the results of this study it can be concluded that atonic solution has no significant effect on increasing total dissolved carbohydrate content of plantlet of Siam Pontianak Orange. 


\section{PENDAHULUAN}

Jeruk merupakan tanaman buah tahunan yang berasal dari Asia, yang diintroduksi dan sudah ditumbuhkan dengan baik di Indonesia secara alami dan budidaya. Tanaman jeruk yang ada di Indonesia adalah peninggalan orang Belanda yang mendatangkan jeruk manis dan keprok dari Amerika dan Italia (Kemal Prihatman, 2000).

Jeruk Keprok Batu 55 mempunyai tinggi tanaman rata-rata 2,25 rn, dapat berumur sampai 15 tahun, relatif bulat, bentuk tanaman speroid, cabang rapat mengarah keatas, diameter batang atas rata - rata $8,5 \mathrm{~cm}$, daun berwarna hijau sepanjang tahun dengan tipe daun tunggal dan berbentuk oval, jumlah bunga per tandan $2-6$ kuanturn dan bentuk bijinya oval. Jeruk Keprok batu 55 memiliki buah berbentuk oblate, dengan warna kulit kehijauan dan permukaan kulit buah kasar agak bergelombang. Jurnlah buah per tandan 2 - 5 buah bobot buah rata -rata mencapai 110,62 gram (Balai PATP, 2013)

Keunggulan jeruk keprok varietas 55 mampu beradaptasi dengan baik didaerah dengan ketinggian 700 - $1200 \mathrm{~m}$ dpl. varietas potensial ini dikembangkan secara komersial sebagai tanaman pot atau sebagai tanaman dilapangan oleh agro industri tanaman buah. Tanaman ini juga banyak diminati petani dan konsumen karena memiliki daging buahnya yang manis, agak masam dan segar (Balai PATP, 2013)

Cekaman kekeringan merupakan faktor utama penyebab kematian dalam budidaya anggrek. Kekeringan pada tanaman anggrek dapat disebabkan karena kelembaban yang rendah dan ketersediaan air yang kurang (Hendaryono, 2000). Menurut Haryati (2003), kekurangan air dapat mengganggu aktivitas fisiologis maupun morfologis sehingga dapat menghentikan pertumbuhan. Cekaman kekeringan pada tanaman dapat disimulasikan dengan menginduksi (PEG) dengan berat molekul lebih dari 4000 pada medium in vitro karena tidak menyebabkan tanaman keracunan (Lawyer, 1970). PEG yang larut sempurna dalam air mempunyai kemampuan menurunkan potensial air, sehingga dapat mengetahui respon jaringan yang ditanam terhadap cekaman kekeringan, serta mengisolasi varian sel atau jaringan yang toleran terhadap cekaman kekeringan sehingga dapat digunakan untuk mengsimulasi besarnya potensial air tanah (Badami dan Amzeri, 2010).

Salah satu upaya peningkatan produksi tanaman jeruk keprok batu 55 yaitu dengan pemberian Zat Pengatur Tumbuh (ZPT), salah satu ZPT yang bisa digunakan yaitu atonik. Atonik merupakan zat perangsang tumbuhnya akar, mengaktifkan penyerapan unsur hara, 
meningkatkan keluarnya kuncup dan buah, serta dapat memperbaiki kualitas tanaman (Sumiati, 2001).

Tanaman yang mampu beradaptasi dengan kondisi cekaman kekeringan dapat menghasilkan senyawa-senyawa osmoregulasi yang dapat menurunkan potensial osmotik, dan penyesuaian tekanan osmotik antara lain dilakukan melalui peningkatan prolin didalam daun tanaman yang toleran terhadap cekaman kekeringan memiliki mekanisme untuk bertahan dalam kondisi kekeringan (Hamim et al., 1996). Cekaman kekeringan yang terjadi pada tanaman dapat menyebabkan kandungan prolin meningkat, karena disebabkan biosintesis prolin dengan prosesnya dapat meliputi hidrolisis protein dan degradasi oksidatif. Prolin juga sangat berperan dalam mengakumulasi senyawa biokimia yang berperan dalam penyesuain osmotik (Nio Song dan Banyo, 2011).

\title{
METODE PENELITIAN
}

Penelitian ini dilaksanakan pada bulan Oktober 2017 sampai Desember 2017 di Laboratorium Botani, Jurusan Biologi Fakultas Matematika dan Ilmu Pengetahuan Alam Universitas Lampung. Bahan- bahan yang digunakan pada penelitian ini adalah planlet jeruk keprok batu-55 (Citrus reticulata Blanco var. crenatifolia), Polyethylene Glycol (PEG) 6000, medium Murashige skoog, PPM, agar, alkohol 96\%, KOH, HCL, larutan stok dan aquades, prolin, larutan sulfosalisilat, asam ninhydryn, asam asetat glasial, asam fosforat, toluen.

\begin{abstract}
Alat dan Bahan
Alat-alat yang digunakan dalam penelitian ini adalah Laminar Air Flow (LAF) merk ESCO yang digunakan untuk mengkultur eksplan, autoklaf untuk sterilisasi alat dan medium, mortar, pestle, sentrifuge yang digunakan untuk menghomogenkan larutan, pinset, scalpel, mata pisau scalpel, kertas filter Whatman no. 1, erlenmeyer berukuran $100 \mathrm{ml}$ dan $1000 \mathrm{ml}$, cawan petri, botol kultur, gelas ukur bervolume $100 \mathrm{ml}$ dan $500 \mathrm{ml}$, mikropipet, pipet tip, mikroskop, spektofotometer,tabung reaksi, Alumunium foil,solasiban bening, plastik wrap, tabung reaksi, rak tabung, timbangan analitik, tisu dan kamera HP iphone 6s.
\end{abstract}

\section{Prosedur}

Penelitian ini dilakukan dalam percobaan faktorial $3 \times 3$. Faktor A adalah atonik dengan 3 taraf konsentrasi : 0 mL/L, 2 mL/L, dan 3 mL/L. Faktor B adalah PEG 6000 dengan 3 taraf 
konsentrasi : $0 \% \mathrm{~b} / \mathrm{v}, 2 \% \mathrm{~b} / \mathrm{v}$, dan $4 \% \mathrm{~b} / \mathrm{v}$. Setiap kombinasi perlakuan diulang 3 kali sehingga jumlah satuan percobaan adalah 27. Parameter dalam penelitian ini adalah nilai tengah $(\mu)$ semua variabel pertumbuhan planlet jeruk keprok batu-55.

\section{Sterilisasi Alat}

Alat-alat gelas dan dissecting set (Scalpel, mata Scalpel, pinset) dicuci dengan detergen kemudian alat-alat tersebut dicuci dengan menggunakan air mengalir dan diautoklaf.Alat dari bahan gelas ditutup dengan plastik, sedangkan alat-alat dari bahan logam dan cawan petri dibungkus menggunakan kertas HVS. Semua alat tersebut disterilisasi dalam autoklaf pada temperatur $121^{0} \mathrm{C}$, selama 30 menit.

\section{Persiapan Medium Tanam}

Medium yang digunakan dalam penelitian ini adalah Murashig dan Skoog (MS) padat. Pembuatan medium tanam MS sebanyak 1 liter adalah dengan cara memipet sejumlah larutan stok, kemudian dimasukkan ke dalam labu takar 1 liter. Akuades ditambahkan sampai tanda 1 liter dan ph diatur sampai 5,5 dilakukan penambahan $\mathrm{KOH} 1 \mathrm{~N}$ atau $\mathrm{HCl} 1 \mathrm{~N}$. larutan tersebut kemudian dipindahkan ke dalam wadah yang lebih besar kemudian ditambahkan agar-agar 7g/L, sukrosa 30g/L, dan PPM 0,5 ml/L. larutan medium dipanaskan untuk melarutkan agaragar (sambil diaduk) sampai mendidih, selanjutnya medium dipanaskan sampai mendidih dan diaduk, kemudian dituangkan ke dalam botol kultur sebanyak 20ml/botol. Sterilisasi medium dengan menggunakan autoklaf dengan tekanan 17,5 psi, $121^{\circ} \mathrm{C}$ selama 15 menit.

\section{Persiapan Medium Seleksi}

Medium (MS) padat ditambahkan (PEG) 6000 dengan konsentrasi 0\%, 2\%, 4\%(b/v), sebelum digunakan (PEG) yang telah dilarutkan dengan akuades pada konsentrasi tertentu disaring menggunakan syringe filter yang mempunyai diameter $0,45{ }_{\mu} \mathrm{m}$ sebanyak 2 kali dilanjutkan filter berdiameter $0,22{ }_{\mu} \mathrm{m}$ satu kali. Penyaringan dilakukan dalam ruang steril di dalam LAF Cabinet. Selanjutnya (PEG) ditambahkan kedalam medium MS. Sebelum diguanakan, medium diinkubasi selama 7 hari pada suhu kamar $\left(25^{\circ} \mathrm{C}\right)$ untuk memastikan bahwa (PEG) telah tersaring dengan baik apabila dalam waktu 7 hari tidak terjadi kontaminasi pada medium, maka medium dapat digunakan. 


\section{Induksi Planlet Dengan Larutan Atonik}

Larutan stok atonik dilarutkan terlebih dahulu dengan akuades pada konsentrasi tertentu disaring menggunakan syringe filter yang mempunyai diameter $0,45{ }_{\mu} \mathrm{m}$ sebanyak 2 kali, dilanjutkan filter berdiameter $0,22 \mu \mathrm{m}$ satu kali. Penyaringan dilakukan dalam ruang steril di dalam LAF Cabinet.Kemudian larutan atonik diencerkan dengan 3 konsentrasi yaitu $0 \mathrm{~mL} / \mathrm{L}$, $2 \mathrm{~mL} / \mathrm{L}, 3 \mathrm{~mL} / \mathrm{L}$ dan selanjutnya dilakukan perendaman akar planlet jeruk keprok batu 55 selama 2 menit.

\section{Persiapan dan Sterilisasi}

Sebelum menanam alat-alat yang akan digunakan terlebih dahulu di setrilisasi dengan cara membakar alat menggunakan alkohol 96\% dan dibakar di atas api bunsen. Planlet direndam dalam detergen selama 5 menit lalu dibilas dengan air mengalir sebanyak 3 kali setelah itu direndam dalam larutan baycelin 20\% selama 2-3 menit. Planlet jeruk keprok batu 55 dibilas dengan akuades, pembilasan dilakukan dua kali. Setelah itu dipindahkan kedalam cawan petri selanjutnya planlet ditanam pada medium seleksi dengan penambahan ZPT berupa atonik.Penanaman planlet jeruk dilakukan didalam LAF Cabinet. Setiap botol kultur ditanami 4 planlet jeruk, sehingga total planlet yang ditanam sebanyak 108 dalam 27 botol kultur. Planlet jeruk tersebut ditumbuhkan hingga menjadi planlet pada medium MS dengan penambahan senyawa (PEG). Diinkubasi kultur dilakukan pada ruangan dengan 1000 lux, 24 jam/hari dari suhu $20{ }^{\circ} \mathrm{C}$.

\section{Analisis Kandungan Prolin}

Daun planlet jeruk keprok diambil kemudian dibersihkan dan ditimbang sebanyak 0,1 gram ( masing-masing perlakuan dilakukan 3 ulangan). Daun ditumbuk dengan mortar di dalam larutan sulfosalisilat 3\% sebanyak $2 \mathrm{ml}$ kemudian disaring dengan kertas saring Whatman no 1. Selanjutnya fitrat diambil sebanyak $0,4 \mathrm{ml}$, dimasukkan ke dalam tabung reaksi dan ditambahkan 0,4 $\mathrm{ml}$ asam ninhydryn. Asam ninhidrin dibuat dengan cara memanaskan 1,25 gram ninhidrin dalam $30 \mathrm{ml}$ asam asetat glasial dan $20 \mathrm{ml}$ asam fosforat. Pemanasan dilakukan dalam waterbath pada suhu $100^{\circ} \mathrm{C}$ hingga larut. Fitrat dalam asam ninhydryn ditambah $0,4 \mathrm{ml}$ asam asetat glasial kemudian dipanaskan pada suhu $100^{\circ} \mathrm{C}$ selama 1 jam, reaksi diakhiri dengan memasukan tabung reaksi berisi filtrat ke dalam gelas piala berisi es. Campuran filtrat, asam ninhydryn dan asam asetat glasial ditambahkan 0,8 ml toluen dan digojok dengan stirrer selama 15-20 detik sehingga terbentuk 2 lapisan cairan berwarna tidak 
sama. Toluen berwarna merah yang mengandung prolin diambil menggunakan pipet tetes, dimasukkan ke dalam kuvet, dan Optical Density (OD) dibaca pada panjang gelombang 520 nm (Bates, 1973).

Kadar prolin dihitung dengan cara membuat larutan standar prolin terlebih dahulu yaitu 0,003 gram prolin standar dilarutkan ke dalam $10 \mathrm{ml}$ asam sulfosalisilat $3 \%$ dan diencerkan. Pengenceran dimaksudkan untuk mendapatkan hasil variasi konsentrasi prolin. Selanjutnya larutan direaksikan dengan asam ninhydrin dan asam asetat glasial, kemudian OD larutan dibaca pada panjang gelombang $520 \mathrm{~nm}$. Hasil absorbansi larutan standar dibuat persamaan regresi linier terlebih dahulu sehingga diperoleh persamaan : $Y=a x+b$. Nilai absorbansi sampel selanjutnya dimasukkan sebagai nilai Y sehingga didapatkan nilai $\mathrm{X}(\mu / \mathrm{mol})$.

Kadar prolin $=(\mu / \mathrm{mol}$ prolin $/ \mathrm{ml}$ tolune $) / 115,13(\mu / \mathrm{mol})$

gram sampel/5

$=\mu$ mol prolin/ gram berat segar sample

(Bates, 1973)

\section{HASIL DAN PEMBAHASAN}

Prolin dapat digunakan sebagai parameter untuk mengetahui ketahanan planlet jeruk keprok batu 55 terhadap cekaman kekeringan, hasil penambahan konsentrasi PEG 6000 pada medium MS. Kandungan prolin planlet jeruk keprok batu 55 yang ditumbuhkan pada medium MS dengan berbagai konsentrasi PEG 6000 (0\%, 2\%, 4\%) dan diinduksi dengan larutan Atonik dengan berbagai konsentrasi $(0 \mathrm{~mL} / \mathrm{L}, 2 \mathrm{~mL} / \mathrm{L}, 3 \mathrm{~mL} / \mathrm{L})$ disajikan pada Tabel 1 .

Hasil analisis ragam menunjukkan bahwa larutan atonik berpengaruh nyata terhadap kandungan prolin pada planlet jeruk keprok batu 55. \{, $\left.F_{\text {hit }}(12,1894)>F_{\text {crit }}(3,5545)\right\}$, sedangkan PEG 6000 berpengaruh nyata terhadap kandungan prolin pada planlet jeruk keprok batu $55\left\{F_{\text {hit }}(54,7894)>F_{\text {crit }}(3,5545)\right\}$. interaksi antara PEG 6000 dengan larutan atonik terhadap kandungan prolin berpengaruh nyata $\left\{F_{\text {hit }}(16,6786)>F_{\text {crit }}(2,9277)\right\}$.

Uji BNT pada taraf 5\% menunjukkan bahwa kandungan prolin mengalami kenaikan yang terjadi pada perlakuan PEG 6000 dengan konsentrasi (0\%, 2\%, 3\%) setelah diinduksi larutan atonik pada konsentrasi $2 \mathrm{~mL} / \mathrm{L}$ dan $3 \mathrm{ml} / \mathrm{L}$, sedangkan pada perlakuan menggunakan larutan atonik $0 \mathrm{~mL} / \mathrm{L}$ terjadi peningkatan pada konsetrasi PEG 6000 2\% kemudian mengalami penurunan pada konsentrasi PEG 4\%. Kandungan prolin pada perlakuan atonik $0 \mathrm{~mL} / \mathrm{L}$ dan 3 
$\mathrm{mL} / \mathrm{L}$ berbeda nyata dengan perlakuan $2 \mathrm{~mL} / \mathrm{L}$ atonik pada konsentrasi PEG 6000 dengan konsentrasi $0 \%$. Konsentrasi PEG 2\% pada larutan atonik $2 \mathrm{~mL} / \mathrm{L}$ berbeda nyata dengan PEG 6000 konsentrasi $2 \%$ menggunakan atonik $0 \mathrm{~mL} / \mathrm{L}$.

Tabel 1. Analisis Kandungan Prolin planlet Jeruk Keprok Batu 55 (C. reticulata Blanco var.crenatifolia) 3 minggu setelah perlakuan kombinasi atonik dan PEG 6000

\begin{tabular}{lllll}
\hline $\begin{array}{l}\text { PEG } \\
(0 \% \mathrm{~b} / \mathrm{v})\end{array}$ & 0 & 2 & & Atonik $(\mathrm{mL} / \mathrm{L})$ \\
& & $(\mathrm{v} / \mathrm{v})$ & Tengah \\
\hline 0 & $0,235 \pm 0,023^{\mathrm{b}}$ & $0,054 \pm 0,008^{\mathrm{a}}$ & $0,233 \pm 0,011^{\mathrm{b}}$ & 0,174 \\
2 & $0,253 \pm 0,004^{\mathrm{bc}}$ & $0,351 \pm 0,042^{\mathrm{d}}$ & $0,327 \pm 0,029^{\mathrm{cd}}$ & 0,311 \\
4 & $0,239 \pm 0,046^{\mathrm{b}}$ & $0,516 \pm 0,036^{\mathrm{e}}$ & $0,523 \pm 0,035^{\mathrm{e}}$ & 0,426 \\
Nilai & 0,242 & 0,307 & 0,361 & \\
Tengah & & & & \\
\hline
\end{tabular}

Keterangan:

$\mu=\bar{Y} \pm S E$

$\bar{Y}=$ Rata-rata kandungan prolin

$S E=$ Standar error

Angka yang diikuti oleh huruf yang sama tidak berbeda nyatapada taraf 5\% $\operatorname{BNT}(0,05)=0,088$

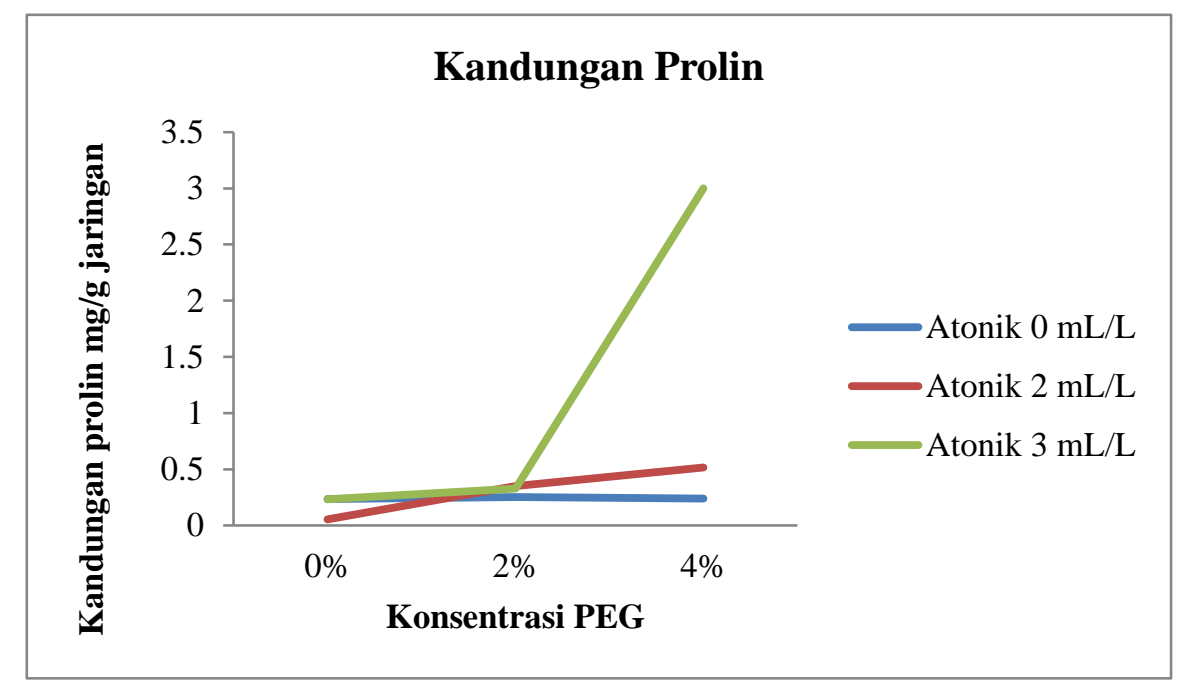

Gambar 1. Kurva Interaksi Kandungan Prolin Daun Planlet Jeruk Keprok Batu 55.

Terjadi perbedaan nyata antara konsentrasi PEG 0\% dengan larutan atonik konsentrasi $2 \mathrm{~mL} / \mathrm{L}$, dan $3 \mathrm{~mL} / \mathrm{L}$. Kandungan prolin yang terdapat di dalam perlakuan menggunakan PEG 
6000 dengan konsentrasi 0\%,2\%, 4\% setelah diinduksi larutan atonik $2 \mathrm{ml} / \mathrm{L}$ mengalami perbedaan nyata yang signifikan, sedangkan kandungan prolin menggunakan PEG 6000 dengan konsentrasi $0 \%, 2 \%$, 4\% setelah diinduksi dengan larutan atonik $3 \mathrm{~mL} / \mathrm{L}$ terjadi perbedaan nyata serta kenaikan yang sangat efisien. Kurva interaksi antara PEG 6000 dan atonik terhadap kandungan prolin disajikan pada Gambar.1

Berdasarkan Gambar 1. terlihat jelas adanya interaksi antara larutan atonik dengan PEG 6000 terhadap kandungan prolin. Hal ini dibuktikan dengan adanya garis singgung pada grafik di atas. Pemberian berbagai konsentrasi PEG 6000 dengan penambahan larutan atonik dapat meningkatkan kandungan prolin dibandingkan dengan pemberian PEG 6000 tanpa larutan atonik. Pemberian PEG 6000 pada konsentrasi 4\% dengan penambahan larutan atonik $3 \mathrm{~mL} / \mathrm{L}$ memiliki kandungan prolin yang lebih tinggi dibandingkan dengan perlakuan lain.

Hasil penelitian ini menunjukkan bahwa penambahan PEG 6000 dengan konsentrasi 4\% setelah ditambahkan larutan atonik $3 \mathrm{~mL} / \mathrm{L}$ menaikkan kandungan prolin secara nyata. Penelitian ini berbanding lurus dengan penelitian Li (2013) yang menyatakan bahwa pengaruh cekaman kekeringan pada benih perkecambahan Eremosparton songoricum tanaman endemik desert dari familia Fabaceae menunjukkan, bahwa kandungan prolin meningkat. Tanaman yang toleran terhadap cekaman kekeringan memiliki akumulasi prolin yang lebih tinggi daripada tanaman yang peka terhadap cekaman kekeringan, dan tingginya akumulasi prolin menunjukkan adanya keterkaitan dengan ketahanan terhadap cekaman kekeringan (Palupi dkk., 2008).

Kadar prolin merupakan karakter yang umumnya digunakan untuk menunjukkan kemampuan toleransi oleh karerenanya karakter pertumbuhan yang digunakan dalam penelitian ini berpotensi untuk dijadikan indikator respon kekeringan pada tanaman. Menurut Badami \& Amzeri (2011) terdapat korelasi antara akumulasi prolin dengan tingkat toleransi terhadap cekaman kekeringan. Cekaman kekeringan yang terjadi pada tanaman dapat menyebabkan kandungan prolin meningkat. Meningkatnya kandungan prolin disebabkan karena biosintesis prolin. Prolin berperan dalam mengakumulasi senyawa biokimia yang berperan dalam penyesuaian osmotik (Ai dan Banyo, 2011). Cara tanaman mengatur tekanan osmotik ketika menghadapi kekeringan diperkirakan merupakan proses adaptif, dengan diproduksinya senyawa terlarut (solute) yang tidak bersifat toksik (termasuk prolin) di dalam sel sehingga mengurangi potensial osmotik saat terjadinya defisir air (Lapanjang, 2008).

Prolin merupakan solut yang dibentuk tanaman untuk bertahan pada kondisi kekeringan sebagai mekanisme mempertahankan turgor sehingga tidak terjadi plasmolisis. Hasil regulasi 
osmotik ini berupa tekanan turgor yang tetap mempertahankan di atas nol, sehingga proses pembelahan sel tetap berlangsung serta menghindari kelayuan yang dapat membahhayakan sel (Naiola, 2005). Kadar prolin pada setiap tanaman berbeda-beda yaitu tidak semua tanaman memproduksi prolin karena pada spesies yang berbeda jenis solut yang diproduksi dimungkinkan bisa berbeda pula misalnya, gula, glycin maupun bethanin (Ashraf dkk., 2007).

Tanaman yang tahan terhadap cekaman kekeringan dapat merespon dengan memproduksi senyawa prolin untuk membantu mempertahankan diri dari dalam kondisi kekurangan air sebagaimana dengan penelitian yang dilakukan Riduan (2005), bahwa tanggapan tanaman terhadap cekaman kekeringan tergantung pada mekanisme fisiologis atau biokima pada masing-masing galur tanaman. Cekaman kekeringan dapat mengakibatkan peningkatan sintesis prolin yang berperan sebagai senyawa osmoprotektan dalam penyesuaian osmotik sel (Hamim dkk., 2008) dan penetralisir senyawa toksik amina. Cekaman kekeringan dapat mengakibatkan terhambatnya sintesis protein menghasilkan asam amino, senyawa volatil, amida, peptida dan amina.

\section{KESIMPULAN}

Berdasarkan dari penelitian ini konsentrasi larutan atonik yang optimum untuk analisis kandungan prolin adalah 3mL/L, sedangkan untuk konsentrasi (PEG) 600 yang toleran untuk analisis kandungan prolin adalah 4\%. Terdapat interaksi antara larutan atonik dengan PEG terhadap analisis kandungan prolin. Kandungan prolin pada planlet jeruk keprok batu-55 dengan perlakuan kombinasi larutan atonik dan PEG 6000 mengalami peningkatan. Semakin tinggi konsentrasi PEG, maka semakin tinggi kandungan prolin.

\section{DAFTAR PUSTAKA}

Ashraf, M., and M.R. Fooland. 2007. Roles of glycine betaine and proline in improving plant abiotic stress resistance. Environmental and Experimental Botany, 59(2), 206-216.

Badami K dan A. Azmeri. 2010. Seleksi In Vitro untuk toleransi terhadap kekeringan pada jagung (Zea Mays L.) dengan Polyethylene Glycol (PEG). Agrovigor 3.1.

Badami K dan A. Azmeri. 2011. Identifikasi Varian Somaklonal Toleran Kekeringan pada Populasi Jagung Hasil Seleksi In Vitro dengan PEG. Agrovior 4.1.

Balai PATP. 2013. Jeruk Keprok Variety Batu 55, (http://www.bpatp.litbang.deptan.go.id). diunduh 09 September 2017 pukul 10.00 WIB. 
Bates, L.S., R.P. Waldren, and I.D. Teare. 1973 Rapid Determination of Free Proline Water Stress Studies. Plant Soil 39:205-207.

Hamim, D. Soepandie, dan M. Yusus. 1996. Beberapa karakterisasi morfologi dan Fisiologi Kedelai toleran dan peka terhadap cekaman kekeringan.Hayati 3: 30-40.

Hamim, K. Ashri, miftahudin, dan Triadianti. 2008. Analisis status air, prolin dan aktivitas enzim antioksidan beberapa kedelai toleran dan peka kekeringan serta kedelai liar. Agrivita 30(30): 201-210.

Haryati. 2003. Pengaruh Cekaman Air Terhadap Pertumbuhan dan Hasil Tanaman. Fakultas Pertanian. USU.

Kemal Prihatman (2000) Sistem Informasi Manajemen Pembangunan di Pedesaan. BAPPENAS, Jakarta.

Lapajang, I., B.S. Purwoko, S.W. Hariyadi, Budi dan M. Melati. 2008. Evaluasi beberapa Ekotipe Jarak Pagar untuk Toleransi Tanaman Kekeringan. Buletin Agronomi, 36(3), 263-269.

Lawyer, D.W. 1970. Absorption of polyethylene glycol by plants the effect on plant growth. New Physiol. (69):501-513.

Li H, X Li, Zhang D, Liu H and K. Guan. 2013. Effects Of Drought Stress On The Seed Germination And Early Seedling Growth Of The Endemic Desert Plant Eremosparton Songoricum (Fabaceae). EXCLI Journal 12:89-101 ISSN 1611-2156

Naiola, B.P. 2005. Akumulasi dan regulasi osmotik dalam sel tumbuhan pada kondisi stres Air. Berita Biologi, 7(6),333-340.

Palupi E.R dan Y. Dedywiryanto. 2008. Kajian Karakter Ketahanan terhadap Cekaman Kekeringan pada Beberapa Genotipe Bibit Bibit Kelapa Sawit (Elaeis guineensis Jacq.). Bul. Agron (36) (1) 24- 32

Riduan, A., H. Aswidinnor., J.Koswara., dan Sudarsono. 2005. Toleransi Sejumlah Kultivar Kacang tanah terhadap Cekaman Kekeringan. Dapartemen Budi Daya Pertanian, Faperta, Institut Pertanian Bogor, kampus Darmaga, Bogor. http:/journal.ipb.ac.id/index.php/hayati/article/download/168/35. [Diakses 20 Desember 2017].

Song. A. N., dan Y. Banyo. 2011. Konsentrasi Klorofil daun Sebagai Indikator Kekurangan Air Pada Tanaman. Jurnal sains 11.2 : 166-173.

Sumiati, E. 2001. Pengaruh Pemberian Zat Pengatur Tumbuh terhadap Hasil, Kualitas dan Umur Simpan Buah Tomat Kultivar Gondol.Jurnal Hortikultura. 11 : 30-39 